\title{
CRITICAL AND CREATIVE THINKING STRATEGIES IN TEACHING INTERNAL CONSISTENCY OF THE RESEARCH TOOL
}

\author{
[STRATEGIE KRITICKEHO A TVORIVEHO MYSLENIA VO \\ VYUCOVANI VNUTORNA KONZISTENCIA VYSKUMNEHO \\ NASTROJA]
}

Jana Duchovicova - Robert Tomsik

\section{doi: 10.18355/PG.2017.6.2.14}

\begin{abstract}
The study presents the results of factor analysis of the Strategies of Critical and Creative Thinking Questionnaire. The questionnaire contains of 40 items that saturate 6 factors - strategies for developing critical thinking in the learning process extracted by factor analysis on a sample of $\mathrm{N}=556$ students. Based on the results of the analysis, the following factors were defined: F1 Strategies for the developing self-regulation; F2 Strategies for developing systematic and interpretative skills; F3 Strategies for developing argumentation; F4 Strategies for developing conclusion and troubleshooting; F5 Strategies for developing evaluation and F6 Strategies for developing reading skills. These factors allow researchers to assess the preferences of specific strategies for developing critical thinking at specific school subjects as well as identify strategies applied by practicing teachers within the teaching practice of student teaching programs, depending on the school subjects (natural science, language, social science, education), type of school (high school, grammar school) and the level of education (lower and upper secondary education).
\end{abstract}

\section{Key words}

critical thinking, strategies for the developing critical thinking, factor analysis

\section{Abstrakt}

Štúdia prezentuje výsledky faktorovej analýzy dotazníka Stratégie kritického a tvorivého myslenia vo vyučovaní. Nástroj obsahuje 40 položiek, ktoré sýtia 6 faktorov - stratégií pre rozvíjanie kritického myslenia vo vyučovacom procese, extrahovaných pomocou exploračnej faktorovej analýzy na vzorke $\mathrm{N}=556$ vysokoškolských študentov. Na základe výsledkov analýzy boli vymedzené faktory: F1 Stratégie na rozvoj sebaregulácie; F2 Stratégie na rozvoj systematických a interpretatívnych zručností; F3 Stratégie argumentácie; F4 Stratégie pre vyvodzovanie záverov a riešenie problémov; F5 Stratégie na rozvoj hodnotenia a F6 Stratégie na rozvoj čitatel'ských zručností. Uvedené faktory umožnia výskumníkom vyhodnotit’ preferencie konkrétnych stratégií rozvíjania kritického myslenia učitel'mi v konkrétnych vyučovacích predmetoch ako aj identifikáciu stratégií uplatňovaných cvičnými učitel'mi v rámci pedagogických praxí študentov učitel'ských programov v závislosti od vyučovaných predmetov (prírodovedné, jazykové, 
spoločenskovedné, výchovné), type školy (SOŠ, gymnázium, II. stupeň ZŠ) a stupňa vzdelávania (nižšie a vyššie sekundárne vzdelávanie).

\section{Kl'účové slová}

kritické myslenie, stratégie na rozvoj kritického myslenia, faktorová analýza

\section{ÚVOD}

K najaktuálnejším problémom odborovej didaktiky v súčasnosti, dotýkajúcich sa oblasti profesijnej prípravy učitel'ov patrí optimálne obsahové a rozsahové vymedzenie praktickej prípravy budúcich učitel'ov $\mathrm{v}$ rámci pregraduálnej prípravy a rozvoj psychodidaktických kompetencií učitel'a pre realizáciu adaptívnych vyučovacích postupov medzi procesmi učenia sa žiaka a procesmi vyučovania s akcentom na výstavbu poznania žiaka. Ide o stratégie stimulácie kritického a tvorivého myslenia učiacich sa subjektov. Uvádzané problémy rezonujú v centre záujmu odborovej didaktiky, pedagogiky a pedagogickej psychológie v súvislosti s výsledkami medzinárodných meraní krajín OECD PISA v oblasti prírodovednej, čitatel'skej, matematickej gramotnosti a riešenia problémov, odporúčaniami úspešných krajín v hodnotení, inováciami v regionálnom školstve, $\mathrm{S}$ rozvojom poznania $\mathrm{v}$ jednotlivých vedných odboroch ako aj v súvislosti rozmachom kognitívnej psychológie a rozvojom poznania voblasti kognitívnych procesov žiaka.

V nadväznosti na potrebu zvyšovania úrovne psychodidaktických kompetencií učitel'ov riešime viaceré výskumné projekty, konkétne. projekt APVV Prax v centre odborovej didaktiky, odborová didaktika v centre praktickej prípravy, ktorého ciel'om je identifikácia adaptívnych vyučovacích stratégií uplatňujúcich kognitívne orientovaný prístup pre rozvoj kritického a tvorivého myslenia v konkrétnych odborových didaktikách a ich implementáciu v pregraduálnej praktickej príprave učitel'ov sekundárneho vzdelávania a projekt VEGA Individuálna koncepcia a stratégia vyučovania $v$ kontexte profesijného rozvoja učitel'a v rámci ktorého sa zameriavame na vypracovanie psychodidaktického kompetenčného profilu učitel'a pre realizáciu kognitívne orientovaných adaptívnych vyučovacích stratégií. Pre potreby naplnenia definovaných ciel'ov sme vytvorili dotazník Stratégie kritického a tvorivého myslenia vo vyučovaní. (Duchovičová a kol. 2017), pričom v predmetnej štúdii sme sa zamerali na analýzu faktorov, ktoré predmetný dotazník identifikuje v kontexte stratégií rozvíjania kritického myslenia.

\section{Teoretické a empirické východiská pre konštruovanie modelu}

Medzinárodné výskumné štúdie (napr. ICMI, TEDS, Preparing Teachers around the World, 2003; Standards of Practic, 2009, 2013), poskytujú pomerne komplexný prehl'ad o vedeckom výskume prípravy učitel'ov jednotlivých predmetov (pričom najpodrobnejšie je preskúmaný systém prípravy učitel'ov matematiky) formou národných prezentácií i medzinárodných komparatívnych výstupov, ktoré umožňujú získat' objektívny pohl'ad na štandard pedagogickej praxe v zahraničí i kvalitu prípravy učitel'a v SR (OECD Talis, 2008, 2013). Analýzou komparatívnych 
štúdií zameraných na profesijnú prípravu budúcich učitel’ov a rozvoj ich expertnosti (Zuljan Valencic, Vogrinc, ed., 2011; Spilkova, Tomkova, 2010; Hattie, 2003) sme identifikovali rozdiely, a to i v porovnaní s krajinami ako je ČR, Pol'sko, v rozsahu praktickej prípravy i v kompetenčných štandardoch praktickej prípravy, najmä $\mathrm{v}$ oblasti konkretizovaných kompetencií a zručností pre uplatňovanie adaptívnych vyučovacích postupov. Uvedené rozdiely sa týkajú najmä kompetencií pre uplatnenie kognitívne orientovaného prístupu, zmysluplného učenia, rozvíjania kritického myslenia žiakov, stimulácie tvorivosti, reflexie učebného štýlu a špecifík v mentálnej štruktúre a koncepcii žiaka. Hoci naznačené témy sú len vybranými kategóriami psychodidaktiky (Duchovicova, Skoda, ed., 2013), ich ponímanie je v kontexte jednotlivých odborových didaktík špecifické. Naznačujú to i snahy výskumu OECD (Innovation Strategy for Education and Training), ktorého sme riešitel'mi, pri definovaní potreby zahrnutia prírodovedne orientovaných, umelecky orientovaných a humanitne orientovaných predmetov $\mathrm{z}$ dôvodu špecifických odborovodidaktických konceptov.

V nadväznosti na medzinárodné snahy podporit' rozvoj kritického a tvorivého myslenia žiakov vo vyučovacom procese je žiaduce aj v našej proveniencii identifikovat' edukačné stratégie, ktoré majú potenciál pre stimuláciu kritického a tvorivého myslenia (Kosturkova, 2012, 2011). V príprave učitel'ov považujeme identifikáciu predmetných stratégií za bazálnu inštrukciu pre kvantitatívnu a kvalitatívnu zmenu v príprave učitel'ov 21. storočia, preto didaktika a najmä jej aplikovaná špecializovaná rovina odborových didaktík hladá a identifikuje stratégie kritického a tvorivého myslenia, ktorých aplikácie je možná už v praktickej pregerduálnej učitel'skej príprave.

Zdrojom pre vymedzenie stratégií rozvoja kritického a tvorivého myslenia je vymedzenie konštruktovej roviny kritického a tvorivého myslenia a dôkazy o tom, že zručnosti kriticky mysliet' je možné vo výchovnovzdelávacom procese priamo ovplyvňovat' (Paul, 1992; Nelson, 1994; Halpern, 2014; Kennedy et all,1991; Abrami, et all, 2008; Bailin et al., 1999; Bonk \& Smith, 1998; Heyman, 2008; Thayer-Bacon, 2000). Vymedzenie konceptu kritického myslenia zostáva aj napriek množstvu filozofických, psychologických i pedagogických pohladov a pokusov (Lai, 2011) stále nejednotné. Hladanie jednotného ponímania stroskotáva na argumentoch podstaty kritického myslenia. Zástancovia filozofického definovania vystavali svoj prístup na vymenovaní hypotetických vlastností kritického myslitel'a, teda na konštrukcii ideálne mysliaceho človeka, alebo opise jeho správania. (Ennis, 1985, Lipman, 1988, Paul, 1992, Bailin et al., 1999). Danému prístupu zodpovedá definícia Facione (1990: 3) „Kritické myslenie je účelné, samoregulované usudzovanie, ktoré pozostáva $\mathrm{z}$ interpretácie, analýzy, hodnotenia a vedie $\mathrm{k}$ záveru, ako aj $\mathrm{k}$ vysvetleniu dôkazných, koncepčných, metodologických kritérií alebo koncepčných úvah.“Všeobecne predstavuje ideál kritického myslitel'a človeka s otvorenou myslou, prirodzene zvedavého, flexibilného, chápajúceho rozmanité hladiská, pátrajúceho po nových informáciách, zvažujúceho rôzne argumenty a rôzne 
riešenia, hl'adajúceho d’alšie perspektívy a argumenty pre formuláciu konečných rozhodnutí. (Facione, 1990).

Predstavitelia kognitívnej psychológie vo vymedzení podstaty kritického myslenia zastávajú názor, že „kritické myslenie predstavuje mentálne procesy, stratégie a reprezentácie, ktoré používajú l'udia na riešenie problémov. Schopnost' rozhodovat' a učit' sa nové pojmy“ (Sternberg, 1986: 3). Kritizujú definície založené na behavioristickom alebo experimentálnom prístupe vymenovania zručností, či presného popisu myšlienkových operácií (štandardov dobrého myslenia) s odôvodnením, že myslenie nie je súhrn diskrétnych, nezávislých krokov, pozorovatel'ných a explicitne vyjadritel'ných postupov vedúcich k meratel’nému výsledku. Van Galder (2005) zdôrazňuje, že myslenie je viac ako súhrn jeho častí. Pedagogický prístup aj napriek kritizovanému hodnoteniu a meraniu výsledkov nachádza bázu práve v definovaní výstupov zo vzdelávania, ktoré sú systémovo rozpracované $\mathrm{v}$ jednotlivých taxonómiách. Taxonómie vzdelávacích ciel'ov predstavujú nástroje umožňujúce hodnotit' myslenie učiacich sa subjektov. Orientácia na pozorovatel'ný výkon žiaka je v didaktickej rovine zároveň ponímaná ako priestor vyjadrenia efektívnosti didaktickej situácie. K najprepracovanejším patrí Bloomova taxonómia (Anderson, Krathwohl, ed (2001), ktorá odvíja výber vzdelávacích stratégií od náročnosti kognitívnych aktivít (zapamätanie, porozumenie, aplikácia, analýza, syntéza, tvorba) a úrovne poznania (obsahuje kategóriu faktických, konceptuálnych, procedurálnych a metakognitívnych poznatkov).

I napriek výraznej nejednotnosti filozofických, psychologických a pedagogických myšlienkových prístupov došlo k snahám dohodnút' sa na vymedzení špecifických schopností obsiahnutých do definície kritického myslenia. Autori, ktorí sa pokúsili o operacionalizáciu sa vo viacerých konštruktoch prekrývajú, preto je spravidla kritické myslenie vymedzované prostredníctvom vymenovania jednotlivých kognitívnych spôsobilostí, ktoré sú následné skúmané vo vzt'ahovej rovine k d’alším zložkám osobnosti (ako sú motivácia, kognitívne schopnosti, tvorivost', črty), či psychickým procesom (učenie, pozornost'...) alebo ostatným bazálnym zručnostiam (čítanie, písanie). Podl'a Lai, (2011) dominujú najmä:

- analýza argumentov, tvrdení alebo dôkazov (Facione, 1990, Halpern, 2014;

Paul, 1992);

- dedukcia založená na induktívnych alebo dedukitívnych argumentoch (Ennis, 1985, Paul, 1992, Willingham, 2007);

- posudzovanie a hodnotenie (Case, 2005, Ennis,1985; Facione, 1990; Lipman, 1988);

- $\quad$ rozhodovanie alebo riešenie problémov (Ennis, 1985; Halpern, 2014; Willingham, 2007);

- $\quad$ odpovede na otázky na objasnenie (Ennis, 1985);

- definovanie pojmov (Ennis, 1985);

- $\quad$ identifikácia hypotéz (Ennis, 1985, Paul, 1992);

- $\quad$ vysvetlovanie (Facione, 1990);

- $\quad$ verbálne zdôvodnenie najmä vo vzt'ahu $\mathrm{k}$ javom pravdepodobnosti a neistoty (Halpern, 2014); 
- $\quad$ predikcia (Tindal \& Nolet, 1995);

- nazeranie na problém z viacerých strán (Willingham, 2007),

- dôsledná mentálna činnost' zameraná na hodnotenie argumentov, alebo výrokov na formulovanie záverov.

Erwin (2002) vytvoril zoznam kognitívnych spôsobilostí kritického myslenia, ktorý zahŕňa :

- spôsobilost' identifikovat' kl'účové myšlienky a predpoklady $\mathrm{v}$ argumente,

- spôsobilost' rozpoznat' dôležité súvislosti,

- spôsobilost' správne interpretovat' údaje,

- spôsobilost' vyvodzovat' z dostupných informácií logické závery,

- spôsobilost' rozlišovat' fakty a domnienky,

- spôsobilost' vyhodnocovat' spol'ahlivost' dôkazov uvádzaných na podporu tvrdení a dôveryhodnosti autority,

- spôsobilost' prehodnocovat' vlastné presvedčenie,

- efektívne rozhodovanie a riešenie problémov. (In Pascarella, Terenzini, 2005).

V snahe definovat' klúčové konštrukty kritického myslenia pre potreby evaluácie učebných výsledkov sa experti pokúsili o vytvorenie konsenzuálnej definície, ktorú publikovali v Delfskej správe (Facione, 1990:, 2). Kritické myslenie je definované ako „zámerné, regulované, usudzovanie vychádzajúce zdôsledného zváženia dôkazov, konceptov, metód, kritérii a súvislostí, zamerané na interpretáciu, analýzu hodnotenie a vyvodzovanie záverov. Jadro kritického myslenia tvoria dve dimenzie (Ennis, 1985; Facione, 1990; Paul,1992; Halpern, 2014, Bailin at al,1999):

1. konkrétne kategórie kognitívnych spôsobilostí: interpretácia, analýza, hodnotenie, usudzovanie, vysvetl'ovanie, sebaregulácia;

2. dimenzia osobnostných dispozícíi.

Facione (1990) vysvetluje kategórie kognitívnych spôsobilostí a osobnostných dispozícií v zmysle Delphi Report (1990) nasledovne:

- Interpretácia implementuje kategorizáciu, dekódovanie významu a dôležitosti. Prakticky ide o rozpoznanie problému, identifikáciu hlavnej myšlienky, triedenie informácií $\mathrm{v}$ rozsiahlom odbornom texte, jasné vymedzenie pojmov, parafrázovanie, interpretáciu údajov v tabul'kách, grafoch, rozpoznanie významu neverbálnych signálov v komunikácie apod.

- Analýza predstavuje identifikáciu a rozbor argumentov, určovanie vzt’ahov a súvislostí, podobných a rozdielnych znakov, rozpoznanie tvrdení a dôkazov $\mathrm{v}$ argumente, identifikáciu nevyjadrených predpokladov.

- Hodnotenie je posúdenie spolahlivosti tvrdení a kvality argumentov. Zahŕňa tiež hodnotenie spol'ahlivosti zdroja informácií, identifikácia logických medzier v argumentácii, posúdenie silných a slabých stránok alternatívnych teórií, hodnotenie zdôvodnení.

- Usudzovanie predstavuje vyvodzovanie záverov na základe dôkazov, formuláciu alternatívnych návrhov riešení problému, predvídanie dôsledkov. 
- Vysvetl'ovanie zahŕňa predkladanie záverov, výsledkov, prezentovanie v podobe tabuliek, schém, tvorbu modelov vyjadrujúcich vzt'ahy medzi premennými, zdôvodňovanie postupov, metodologického prístupu, formuláciu argumentov, anticipáciu protiargumentov.

- Sebaregulácia je monitorovanie a korekcia vlastných myšlienkových procesov, identifikácia emócií, predsudkov, stereotypov, kognitívnych skratiek, vo vlastnom usudzovaní a argumentácii, kontrola primeranosti zvolenej stratégie riešenia problému.

Osobnostné dispozície spojené s kritickým myslením sú vymedzené nasledovne:

- široký okruh záujmov,

- snaha byt' dobre informovaný,

- dôvera v silu rozumu a vlastný úsudok,

- otvorenost' mysle voči rozmanitým svetonázorom,

- ochota vziat' do úvahy rôzne alternatívy, a hl'adiská a nezaujato posúdit' zdôvodnenia,

- opatrnost' pri utváraní záverov,

- ochota priznat' si egocentrické sklony, predsudky, stereotypy a logické medzery vo vlastnom uvažovaní,

- ochota znovu prehodnotit' vlastné stanovisko.

Kritické myslenie sa vymedzuje oproti štandardne skúmaným konceptom: tvorivosti, motivácii, metakognícii ako jedinečná zručnost', ktorú nie je možné so žiadnym z nich stotožnit'. Lipman (1988) poukázal na to, že metakognícia nepredstavuje kritický prístup, pretože ak človek uvažuje nad svojim myšlienkovým postupom môže tak robit' nereflexívnym spôsobom. Metakognícia však môže byt' považovaná za podpornú zručnost' pre kritické myslenie, tým, že monitorovanie kvality myšlienok vedie ku zvyšovaniu kvality myslenia. Vzt'ah motivácie a kritického myslenia je založený podl’a Halpern (2014) na dvoch hlavných zložkách motivácie, ktorými sú úsilie a vytrvalost'. Bez nich nie je možné rozvinút' ani kritické myslenie. Výrazná výskumná pozornost' je venovaná vzt'ahovej rovine kritického a tvorivého myslenia (Bailin, 2002, Paul \& Elder, 2006, Thayer-Bacon, 2000) a hoci sú pohl'ady rôznorodé, väčšina autorov sa prikláňa $\mathrm{k}$ názoru vzájomnej komplementarity oboch procesov prejavujúcej sa napr. pri tvorbe hypotéz, hlaadaní alternatívnych vysvetlení určitého javu, riešení problémov. Bailin (2002) sa domnieva, že pre kritické myslenie je určité množstvo kreativity nevyhnutné. Paul \& Elder (2006) poznamenávajú, že kreativita a kritické myslenie sú aspekty „dobrého“ a účelného myslenia a kritické myslenie a kreativita predstavujú dve strany jednej mince. Účelné myslenie si vyžaduje schopnost' vedome a strategicky vytvárat' intelektuálne produkty, ktoré sú priamo spojené s kreativitou. Obidva koncepty sú neoddelitel’ne prepojené a paralelne sa rozvíjajú. Preto autori zdôrazňujú nutnost' kreatívne a kritické myslenie integrovat' počas výučby. Ako poznamenávajú autori, kritické myslenie bez tvorivosti sa znižuje len na skepticizmus a negativizmus a kreativita bez kritického myslenia sa zužuje len na originalitu.

Jednotlivé kritériá kritického a tvorivého myslenia sú, resp. by mali byt' následne elementami vzdelávacích stratégií učitel'ov a študentov učitel'ských študijných programov. Ide o psychodidaktickú kompetenciu učitel'ov, kde sú 
pri výbere edukačnej stratégie priamo jednotlivé kritériá efektívneho myslenia implementované. Kl'účové psychodidaktické témy zahŕňajúce stimuláciu kritického a tvorivého myslenia, metakognície, motivácie a d'alších kognitívnych funkcií sa stali paradigmou kognitívnej edukácie a kognitívne orientovaného vyučovania a sú zásadným zdrojom inovácií didaktických stratégií v celom spektre odborových didaktík v svetovom meradle.

Rozvíjanie kritického myslenia si podl'a Kneedler (1985) vyžaduje rozvoj spôsobilosti:

1. spôsobilosti určit', definovat' a špecifikovat' problém, t.j. identifikovat' hlavné východiská, sporné otázky, určit hlavnú myšlienku textu, porovnat' podobnosti a rozdiely medzi dvomi, alebo viacerými subjektmi, objektmi v tom istom časovom slede, určit', ktoré informácie sú dôležité, a ktoré nepodstatné, formulovat' vhodné otázky vedúce $\mathrm{k}$ hlbšiemu porozumeniu situácie,

2. spôsobilosti posúdit' informácie vzt'ahujúce sa k problému, t.j. rozlišovat' fakty, názory a odôvodnené úsudky, aplikovat' kritéria na posúdenie kvality, kontrolovat' konzistentnost' výrokov, určit' nevyslovené predpoklady, rozpoznat' stereotypy, hodnotové systémy, rozpoznat' predpojatost', emočné faktory, propagandu, rôzne ideológie.

3. spôsobilost' vyvodzovat' závery t.j určit' vhodnost' a primeranost' údajov pre daný záver, predpovedat' pravdepodobné dôsledky prijatého riešenia.

Na základe prác Paul (1993); Facione et. al. (1998); King (1995); Arangie (1997) a d'alších navrhli Simpson, Courtney (2007) model kritického myslenia, ktorý implementujúc kognitívne a dispozičné zručnosti, definuje stratégie a kritériá, ktoré by mali v edukácii byt' uplatňované.
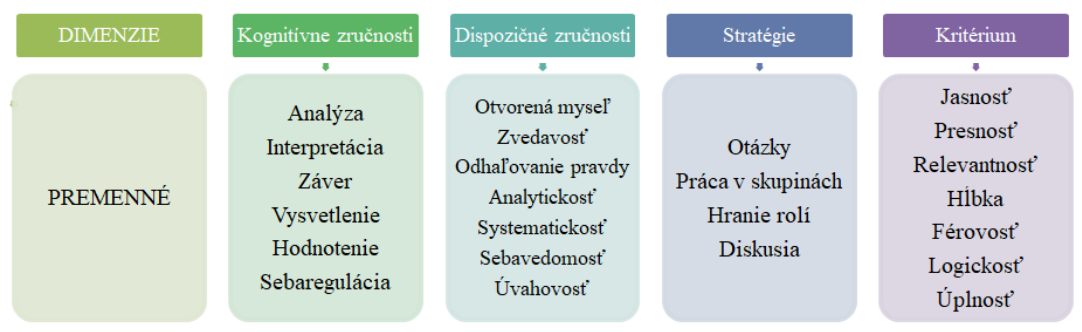

Obrázok 1 Model kritického myslenia. (Simpson, Courtney, 2007: 57)

V rámci stratégií rozvíjania kritického myslenia boli zahrnuté najmä otázky a diskusia, kooperatívne vyučovanie a aktivizujúca metóda hranie rolí. Case (1994) a King (1995) tvrdia, že základný predpoklad kritického myslitel’a je zvedavost'. Dobrí myslitelia sú dobrí práve preto, že sa vel'a pýtajú, kladú množstvo otázok k javom, ktoré videli, prečítali si o nich, počuli alebo sa nejako viažu k ich skúsenosti, zážitku. Otázky formulujú najčastejšie nasledovným spôsobom: Čo je podstatou toho?; Čo to znamená?; Prečo sa to deje?; Čo keby? (King, 1995). Walsh (1997) vidí význam stratégie kladenia kritických otázok v tom, že umožňujú žiakom predvídat' výsledky a tvorit' Slavonic Pedagogical Studies Journal, ISSN 1339-8660, Volume 6 Issue 2, September 2017 
alternatívy pre riešenie problémov, ktorým čelia. Diskusia alebo debata je, ako poznamenáva Bell (1991:6) nositel'om analýzy, kritickosti a budovania argumentov a efektívnost' debaty vidí v rozvíjaní zručnosti argumentácie. Priestor „otvoreného bádania“ a diskusie poskytuje študentom príležitost' skúmat' svoje vlastné pocity, postrehy a názory. To má za následok, že študent sa stále viac zoznamuje $\mathrm{s}$ témou, napadajú ho nové myšlienky, vyvracia fakty a posilňuje svoje komunikačné zručnosti a predstavuje inovatívny spôsob učenia. Práca $\mathrm{v}$ malej skupine povzbudzuje interakciu účastníkov a umožňuje im, aby sa podelili o svoje myšlienky pre analýze a vyvodzovaní jednotlivých predpokladov. Študenti majú možnost' porovnat' názory a konfrontovat' jednotlivé štýly kritického myslenia rovesníkov so svojim. Malé skupiny majú vplav aj na rozvoj dispozičných zručností, pretože sú menej ohrozujúce a zvyšujú pohodlie $\mathrm{k}$ formulácii otázok, pri ktorých účastníci nemusia mat odpovede. Táto metóda podporuje kooperatívne zručnosti $\mathrm{v}$ rovesníckych skupinách a socializáciu. Autori zdôraznili, že koopretatívne vyučovanie je účinný prostriedok pre rozvoj rozhodovania a riešenie problémov hranie rolí. „Post-play“ diskusia dáva zároveň učitel'om možnost' vytvorit' priestor pre analýzu a následne tvorbu nových myšlienok. Pomocou hrania rolí, môžu žiaci byt' zase uvedení do okolností, ktoré sú v rozpore s ich 'normálnym' životnými okolnostami, teda poskytujú jedinečnú možnost' ocenit' alternatívne pohl'ady a názory.

Ďalší autori (Erduran \& Jimenez 2008;) zameriavajú pozornost' na využívanie stratégií rozvíjajúcich argumentačné zručnosti. Argumentačné metódy vo vyučovacom procese podporujú rozvoj kognitívnych a metakognitívnych spôsobilostí, komunikačných kompetencií, spôsobilostí hovorit' a písat' jazykov kedy a formujú návyky a osobnostné vlastnosti potrebné pre kritické myslenie ako sú zvyk hodnotit' opodstatnenost' vlastných presvedčení, identifikovat' predsudky a zaujatost' vo vlastnej argumentácii. vyhýbanie citovo zafarbeným slovám, vágnym a viacznačným vyjadreniam, zručnost' správne rekonštruovat' myšlienky iných, vyhýbat' sa dezinterpretácii skutočnosti pre vlastné potreby a pod.

Z analýz vzdelávania učitel’ov $\mathrm{v}$ krajinách dosahujúcich najlepšie výsledky $\mathrm{v}$ medzinárodných hodnoteniach je zrejmé, že najväšší dôraz je kladený na prepracovaný systém reflektovanej, štruktúrovanej, stupňovitej učitel'skej praxe implementujúcej poznatky o procesoch poznávania žiakov a rozvíjaní ich kritického a tvorivého myslenia, čo predstavuje klúčové psychodidaktické témy. Psychodidaktické témy vedú $\mathrm{k}$ zmenám pohl'adu učitel'ov na vyučovanie, umožňujú im vidiet' vyučovací proces v širších súvislostiach, uvedomit' si podstatu mnohých problémov a nachádzat' možnosti ich riešenia, čím sa stávajú významným zdrojom inovácií $\mathrm{v}$ samostatnom pedagogickom myslení, kritickej analýze a hodnotení jednotlivých didaktických koncepcií a rozširuje sa základ, na ktorom učitel' uskutočňuje svoje didaktické rozhodnutia.

\section{Štruktúra výskumného nástroja: Zahrnuté stratégie kritického a tvorivého myslenia}

V našej štúdii, vychádzajúc $\mathrm{z}$ citovaných autorov a analyzovaných teórií kritického myslenia a d’alších prác (Capek, 2015; Fisher, 2004; Obrancova, 
a kol., 2004; Kosturkova, 2012; Skalkova, 2004 a d'alší) v snahe identifikovat' uplatňovanie stratégii kritického a tvorivého myslenia s dôrazom na rozvíjanie konkrétnych zložiek kritického myslenia učitel'mi, identifikáciu preferencie konkrétnych stratégií, identifikáciu stratégii uplatn̆ovaných cvičnými učitel'mi v závislosti od vyučovaných predmetov (prírodovedné, jazykové, spoločenskovedné, výchovné), type školy (SOŠ, gymnázium, II. stupen̆ ZŠ) a stupňa vzdelávania (nižšie a vyššie sekundárne vzdelávanie) sme formulovali rozmanité edukačné stratégie kritického myslenia a tvorivého myslenia, ktoré napomáhajú k rozvoju jednotlivých faktorov kritického myslenia a tvorivosti. Formulované stratégie predstavovali konkrétne položky výskumného nástroja, ktoré sme pre potreby príslušnosti $\mathrm{ku}$ konštruktu kritického myslenia a tvorivosti podrobili exploračnej faktorovej analýze. Výskumný nástroj tvorilo 40 položiek (5 stupňová škála), na ktoré respondenti (študenti učitel’ských študijných programov) odpovedali prostredníctvom miery súhlasu na pät'stupňovej škále Likertovho typu. Zámerom výberu vzorky bola $\mathrm{v}$ tomto prípade potreba skvalitňovania pedagogickej praxe sústredením pozornosti na aplikáciu stratégií kritického a tvorivého myslenia cvičnými učitel'mi priamo vo vyučovacom procese, ktorý je študentmi pozorovaný a analyzovaný a tiež reflektovaný do tvorby vlastnej vyučovacej stratégie študenta, čím je rozvíjaná psychodidaktická kompetencia budúceho učitel'a.

Pri tvorbe vlastného modelu rozvoja kritického myslenia žiakov sme pre definovanie zložiek stratégií kritického myslenia vychádzali z kognitívnych a dispozičných spôsobilostí kritického myslenia a vybraných stratégií, ktoré sme podrobili faktorovej analýze, pričom sme očakávali, že výsledkom tejto analýzy budú faktory sýtiace stratégie na rozvoj kognitívnych zručností, stratégie na rozvoj dispozičných zručností, stratégie na rozvoj tvorivého myslenia, stratégie podporujúce analýzu a syntézu, induktívno-deduktívne stratégie a stratégie riešenia problémov.

Tabul'ka 1 Edukačné stratégie zahrnuté v dotazníku Stratégie kritického a tvorivého myslenia vo vyučovaní (Duchovicova a kol. 2017).

\begin{tabular}{|c|l|}
\hline Číslo & \multicolumn{1}{|c|}{ Položka dotazníka } \\
\hline 1 & Využívanie práce malých skupín vo vyučovaní \\
\hline 2 & Využívanie problémového vyučovania \\
\hline 3 & $\begin{array}{l}\text { Využívanie diskusie ako priestoru pre skúmanie vlastných pocitov } \\
\text { postrehov a názorov žiakov }\end{array}$ \\
\hline 4 & Vytváranie priestoru pre žiacke objavovanie, zvedavost', skúmavost' \\
\hline 5 & Využívanie podobností a analógií \\
\hline 6 & Využívanie projektového vyučovania \\
\hline 7 & $\begin{array}{l}\text { Vytváranie priestoru pre sebaprezentáciu, prezentáciu vlastných } \\
\text { riešení žiakov }\end{array}$ \\
\hline 8 & $\begin{array}{l}\text { Vytváranie priestoru pre prezentovanie rôznych názorov, postojov } \\
\text { a kultúrnych odlišností medzi žiakmi }\end{array}$ \\
\hline
\end{tabular}




\begin{tabular}{|c|c|}
\hline 9 & h s väčším počtom správnych riešení \\
\hline 10 & $\begin{array}{l}\text { Vedenie k zhrnutiu a interpretácii učiva (povedat' učivo vlastnými } \\
\text { slovami) }\end{array}$ \\
\hline 11 & Využívanie postupov na pochopenie \\
\hline 12 & $\begin{array}{l}\text { Identifikácia a vymedzenie základných pojmov a vzt’ahov učitel'om, } \\
\text { tvorba poznámok }\end{array}$ \\
\hline 13 & $\begin{array}{l}\text { Využívanie asociácií (prvotné predstavy spojené s istým pojmom, } \\
\text { javom) }\end{array}$ \\
\hline 14 & $\begin{array}{l}\text { Preferencia kognitívne náročnejších úloh (úlohy na analýzu, } \\
\text { hodnotenie, tvorivost') s jedným správnym riešením }\end{array}$ \\
\hline 15 & Vedenie žiakov k tvorbe originálnych myšlienok, riešení a produktov \\
\hline 16 & $\begin{array}{l}\text { Využívanie kategorizácií (zarad'ovanie - roztried'ovanie na základe } \\
\text { určitého kritéria) }\end{array}$ \\
\hline 17 & $\begin{array}{l}\text { Vedenie žiakov k dedukcii, konkretizácií (vyvodzovanie konkrétnych } \\
\text { príkladov zo všeobecných teórií) }\end{array}$ \\
\hline 18 & Využitie postupov na zapamätávanie \\
\hline 19 & Využívanie rôznych zdrojov (okrem učebnice) \\
\hline 20 & $\begin{array}{l}\text { Využívanie debaty vo vyučovaní (vedenie } \mathrm{k} \text { tvorbe analýz } \\
\text { a argumentov) }\end{array}$ \\
\hline 21 & $\begin{array}{l}\text { Vedenie } \mathrm{k} \text { formulovaniu otázok podporujúcich myslenie (otázky } \\
\text { typu: Čo je podstatou toho? Čo to znamená? Prečo sa to deje? Čo } \\
\text { keby? a pod.) }\end{array}$ \\
\hline 22 & $\begin{array}{l}\text { Vytváranie priestoru pre prezentovanie žiakových myšlienok, ich } \\
\text { konfrontáciu a zdokonalovanie }\end{array}$ \\
\hline 23 & Riešenie problému a navrhovanie záverov \\
\hline 24 & Veden \\
\hline 25 & Rešpek \\
\hline 26 & ch a úlohách \\
\hline 27 & $\begin{array}{l}\text { ázorňovaniu učiva (pojmové mapy, } \\
\text { zornenia) }\end{array}$ \\
\hline 28 & Využivanie hrania rolí \\
\hline 29 & Využitie protirečení a rozporov, vedenie $\mathrm{k}$ argumentácii \\
\hline 30 & $\begin{array}{l}\text { Vedenie žiakov k hodnoteniu dôveryhodnosti zdroja, vedenie } \\
\mathrm{k} \text { argumentácii }\end{array}$ \\
\hline 31 & Vedenie žiakov k identifikácii rozdielov medzi faktom a názorom \\
\hline 32 & Vedenie žiakov k vyvodzovaniu záverov a k zovšeobecňovaniu \\
\hline 33 & Kladenie otázok zameraných na opakovanie zapamätaného učiva \\
\hline 34 & Vedenie žiakov k identifikácii príčiny a následku \\
\hline 35 & $\begin{array}{l}\text { Štruktúrovanie učiva na základe vymedzených ciel'ov podla } \\
\text { konkrétnych taxonómií (Bloom, Simpson, Harrow, Krathwohl, } \\
\text { Tollinger....) }\end{array}$ \\
\hline
\end{tabular}




\begin{tabular}{|c|l|}
36 & $\begin{array}{l}\text { Vedenie žiakov k identifikácii kl'účových a relevantných faktov a } \\
\text { myšlienok v učive }\end{array}$ \\
\hline 37 & Vedenie k práci s textom a k tvorbe vlastných poznámok \\
\hline 38 & Vytváranie prezentácií a podporných učebných materiálov pre žiakov \\
\hline 39 & Využívanie digitálnych učebných materiálov, programov a aplikácií \\
\hline 40 & $\begin{array}{l}\text { Využívanie grafických znázornení pri prezentácií učiva (pojmové } \\
\text { mapy, handout, tabul'kové, grafické znázornenia) }\end{array}$ \\
\hline
\end{tabular}

\section{Výskumný súbor}

Výskumnú vzorku tvorilo $\mathrm{N}=556$ vysokoškolských študentov študijných programov v odbore Učitel'stvo akademických predmetov (jednoodborové a v kombinácii). Do výskumu boli zaradení študenti bakalárskeho $(\mathrm{N}=342)$ štúdia a magisterského $(\mathrm{N}=214)$ stupňa štúdia. $Z$ celkového počtu participantov výskumu bolo $\mathrm{N}=88$ respondentov a $\mathrm{N}=468$ respondentiek. Priemerný vek respondentov bol $\mathrm{M}=24,48$ rokov so štandardnou odchýlkou $\mathrm{SD}=2,68 \mathrm{roku}(\min =21 ; \max =44)$

\section{VÝSLEDKY}

$\mathrm{Na}$ identifikáciu jednotlivých faktorov bola použitá exploračná faktorová analýza (Principal Axis Factoring s Varimaxovou rotáciou; štatistický program SPSS ver. 21). Pre výber konečného počtu faktorov pre výskumný nástroj sme primárne použili grafické znázornenie Scree plot. Subjektívny Scree test je bodový graf čísel redukovanej korelačnej matice (Eigenvalues; Tabul'ka 1) zoradených podl'a vel'kosti, pri ktorom sa extrahujú tie faktory, ktoré spadajú do časti krivky, ktorá je pred posledným vel'kým poklesom v grafe. Scree test udával, že je realistické uvažovat' o šiestich faktoroch (Graf 1).

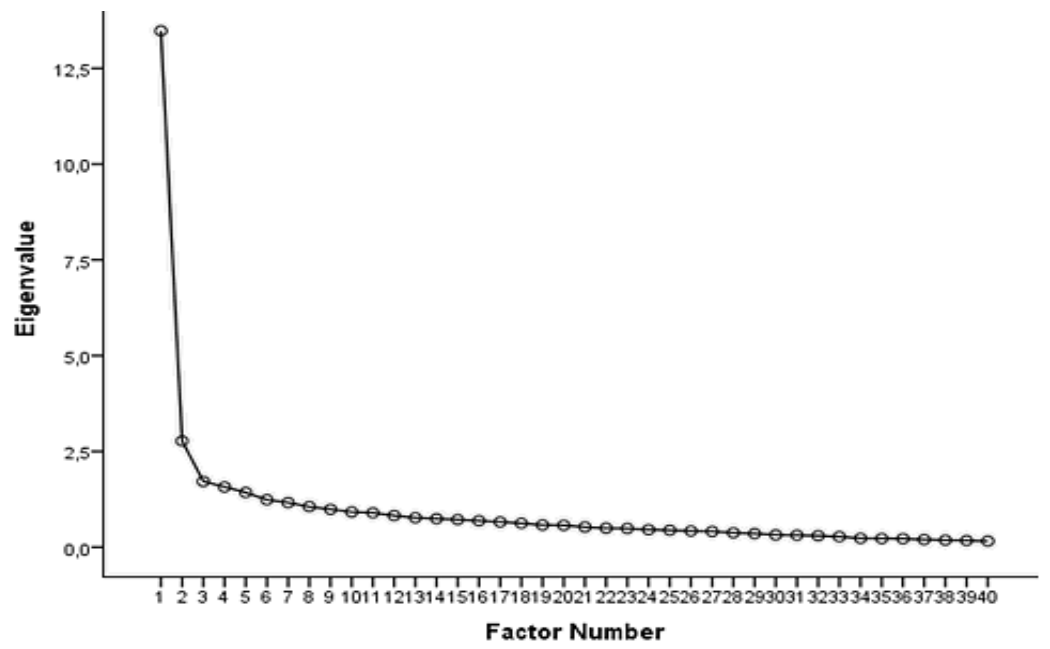

Graf 1 Scree plot. 
Počet možných faktorov sme určili Kaiserovou metódou. Prostredníctvom analýzy bolo extrahovaných šest' faktorov, ktoré mali hodnoty $>1$. Model vysvetl'oval $47,972 \%$ variability v skúmanom súbore. Najvyššiu čast' variability premenných vysvetl'ujú faktory 1 a $2(13,477 \% ; 2,773)$. Faktory 3 až 6 vysvetl'ujú variability premenných v rozmedzí 1,717 \% do $1,240 \%$ (Tabul'ka 2).

Tabul'ka 2 Variabilita faktorov

\begin{tabular}{|c|c|c|c|c|c|c|}
\hline \multirow{2}{*}{ Faktor } & \multicolumn{3}{|c|}{ Počiatočné Eigenvalues } & \multicolumn{3}{c|}{ Rotované súčty kvadratických zátaži } \\
\cline { 2 - 7 } & Spolu & $\begin{array}{c}\% \\
\text { odchýlky }\end{array}$ & $\begin{array}{c}\text { Kumulatívne } \\
\%\end{array}$ & Spolu & $\begin{array}{c}\% \\
\text { odchýlky }\end{array}$ & Kumulatívne \% \\
\hline 1 & 13,477 & 33,693 & 33,693 & 4,482 & 11,205 & 11,205 \\
\hline 2 & 2,773 & 6,932 & 40,625 & 3,936 & 9,840 & 21,045 \\
\hline 3 & 1,717 & 4,293 & 44,918 & 3,255 & 8,137 & 29,183 \\
\hline 4 & 1,573 & 3,933 & 48,851 & 2,936 & 7,340 & 36,523 \\
\hline 5 & 1,428 & 3,570 & 52,421 & 2,591 & 6,478 & 43,002 \\
\hline 6 & 1,240 & 3,100 & 55,521 & 1,988 & 4,971 & 47,972 \\
\hline
\end{tabular}

Sýtenie položiek jednotlivých faktorov je uvedené v Tabul'ke 3. Pre prehl'adnost' $\mathrm{v}$ tabul'ke uvádzame len hodnoty koeficientov sýtenia nad hladinu 0,300. Do faktorov boli implementované len tie položky, ktoré sýtili jednotlivé faktory nad hladinu 0,300 , avšak ani jedna položka nesýtila faktor pod stanovenú hladinu, tým pádom ani jedna položka nebola z modelu vypustená. Ani jedna z položiek nie je reverzná (Tabul'ka 3).

Tabul'ka 3 Faktorová štruktúra výskumného nástroja.

\begin{tabular}{|c|c|c|c|c|c|c|}
\hline & F1 & F2 & F3 & F4 & F5 & F6 \\
\hline Položka 1 & $\mathbf{0 , 7 2 0}$ & & & & & \\
\hline Položka 2 & $\mathbf{0 , 7 0 2}$ & & & & & \\
\hline Položka 3 & $\mathbf{0 , 6 3 9}$ & & & & & \\
\hline Položka 4 & $\mathbf{0 , 6 2 6}$ & & & & & \\
\hline Položka 5 & $\mathbf{0 , 5 8 5}$ & & & & & \\
\hline Položka 6 & $\mathbf{0 , 5 1 7}$ & & 0,390 & & & \\
\hline Položka 7 & $\mathbf{0 , 5 1 2}$ & 0,425 & & & & \\
\hline Položka 8 & $\mathbf{0 , 4 8 6}$ & 0,376 & & & & \\
\hline Položka 9 & $\mathbf{0 , 4 0 6}$ & & 0,397 & & & \\
\hline Položka 10 & & $\mathbf{0 , 6 5 9}$ & & & & \\
\hline Položka 11 & & $\mathbf{0 , 5 8 8}$ & & & & \\
\hline Položka 12 & & $\mathbf{0 , 5 4 0}$ & & & & \\
\hline
\end{tabular}




\begin{tabular}{|l|l|l|l|l|l|l|}
\hline Položka 13 & & $\mathbf{0 , 5 3 4}$ & & & & \\
\hline Položka 14 & & $\mathbf{0 , 5 2 4}$ & 0,382 & & & \\
\hline Položka 15 & 0,380 & $\mathbf{0 , 5 0 5}$ & & & & \\
\hline Položka 16 & 0,381 & $\mathbf{0 , 4 8 2}$ & & & & \\
\hline Položka 17 & & $\mathbf{0 , 4 1 3}$ & & & & \\
\hline Položka 18 & & $\mathbf{0 , 3 9 4}$ & & & 0,343 & \\
\hline Položka 19 & & & & $\mathbf{0 , 6 2 0}$ & & \\
\hline Položka 20 & & & & $\mathbf{0 , 6 1 0}$ & & \\
\hline Položka 21 & & 0,355 & & $\mathbf{0 , 5 6 2}$ & & \\
\hline Položka 22 & & & & $\mathbf{0 , 4 8 0}$ & & \\
\hline Položka 23 & & & & $\mathbf{0 , 4 4 7}$ & & \\
\hline Položka 24 & & & & $\mathbf{0 , 4 2 7}$ & & \\
\hline Položka 25 & & & & $\mathbf{0 , 3 5 1}$ & & \\
\hline Položka 26 & 0,401 & 0,365 & $\mathbf{0 , 5 2 3}$ & & & \\
\hline Položka 27 & & & $\mathbf{0 , 5 1 8}$ & & & \\
\hline Položka 28 & & & $\mathbf{0 , 4 5 9}$ & & & \\
\hline Položka 29 & & & $\mathbf{0 , 4 1 2}$ & & & \\
\hline Položka 30 & & & $\mathbf{0 , 3 3 5}$ & & & \\
\hline Položka 31 & & & 0,498 & & $\mathbf{0 , 3 2 0}$ & \\
\hline Položka 32 & & & & 0,494 & $\mathbf{0 , 3 3 0}$ & \\
\hline Položka 33 & & & & & $\mathbf{0 , 5 5 2}$ & \\
\hline Položka 34 & & & & & $\mathbf{0 , 4 4 6}$ & \\
\hline Položka 35 & & & & & $\mathbf{0 , 4 0 4}$ & \\
\hline Položka 36 & & & & & $\mathbf{0 , 3 6 6}$ & \\
\hline Položka 37 & & & & & 0,398 & $\mathbf{0 , 3 0 5}$ \\
\hline Položka 38 & & & & & & $\mathbf{0 , 7 2 0}$ \\
\hline Položka 39 & & & & & & $\mathbf{0 , 6 0 4}$ \\
\hline Položka 40 & & & & & 0,367 & $\mathbf{0 , 3 8 0}$ \\
\hline
\end{tabular}

Pozn.: F1 - Stratégie na rozvoj sebaregulácie; F2 - Stratégie na rozvoj systematických a interpretatívnych zručností; F3 - Stratégie argumentácie; F4 - Stratégie pre vyvodzovanie záverov a riešenie problémov; F5 Stratégie na rozvoj hodnotenia; F6 - Stratégie na rozvoj čitatelských zručností. 
$\mathrm{V}$ rámci výskumu, extrakcie faktorov výskumného nástroja Stratégie kritického a tvorivého myslenia vo vyučovaní, bola zist'ovaná aj reliabilita celého nástroja a jeho jednotlivých subškál prostredníctvom Cronbachovho alfa koeficientu. Cronbachov alfa koeficient na úrovni jednotlivých subškál sa pohybuje od $\alpha=0,811$ do $\alpha=0,943$ a pre celú škálu $\alpha=0,979$. Verzia vytvorená na základe exploračnej faktorovej analýzy so šiestimi subškálami mala Cronbachov alfa koeficient pre subškálu Stratégie na rozvoj kognitívnych zručností $\alpha=0,936$ (8 položiek), Stratégie na rozvoj dispozičných zručností $\alpha=0,925$ (7 položiek), Stratégie na rozvoj analytického, syntetického a tvorivého myslenia $\alpha=0,943$ ( 9 položiek), Riešenie problémov $\alpha=0,811$ ( 5 položiek), Štrukturovanie učiva $\alpha=0,861$ (4 položky), Stratégie na rozvoj induktívneho a deduktívneho myslenia $\alpha=0,888$ (6 položiek). Alfa koeficient jednotlivých subškál je vysoký, čiže ani jedna zo subškál sa nejaví ako problematický faktor z hl'adiska vnútornej konzistencie výskumného nástroja.

\section{DISKUSIA}

Na základe výsledkov exploračnej faktorovej analýzy môžeme konštatovat', že dotazník Stratégie kritického a tvorivého myslenia vo vyučovaní pozostáva zo šiestich faktorov, ktoré sú sýtené 40 položkami. Vyšpecifikoval sa samostatne stojaci faktor Stratégie na rozvoj čitatel'ských zručností súvisiaci najmä so štruktúrovaním učiva (textov a pracovných materiálov) ako nástroja generovania mentálnej mapy a konceptualizácie učebných obsahov. Označenie jednotlivých faktorov vyplynulo z potreby rozčlenenia stratégií pre jednotlivé kognitívne a dispozičné zručnosti v súlade $\mathrm{s}$ vyššie analyzovanými teória kritického myslenia. Jednotlivé faktory je možné, na základe výsledkov štatistických analýz, interpretovat' nasledovne:

Faktor 1: Stratégie na rozvoj sebaregulácie. Faktorová analýza zahrnula do faktoru 9 položiek s nasledujúcimi stratégiami:

- Vytváranie priestoru pre sebaprezentáciu, prezentáciu vlastných riešení žiakov.

- Vytváranie priestoru pre prezentovanie rôznych názorov, postojov a kultúrnych odlišností medzi žiakmi.

- Využívanie diskusie ako priestoru pre skúmanie vlastných pocitov postrehov a názorov žiakov. Využívanie práce malých skupín vo vyučovaní.

- Vytváranie priestoru pre žiacke objavovanie, zvedavost', skúmavost'.

- Využívanie problémového vyučovania.

- Využívanie podobností a analógií.

- Využívanie projektového vyučovania.

- Preferencia úloh s väčším počtom správnych riešení.

Faktor 2 Stratégie na rozvoj systematických a interpretatívnych zručností. Faktorová analýza zahrnula do faktoru 9 položiek s nasledujúcimi stratégiami:

- Vedenie žiakov k dedukcii, konkretizácií.

- Využívanie postupov na pochopenie.

- Využitie postupov na zapamätávanie.

- Vedenie k zhrnutiu a interpretácii učiva. 
- Preferencia kognitívne náročnejších úloh (úlohy na analýzu, hodnotenie, tvorivost') s jedným správnym riešením.

- Využívanie kategorizácií (zarad’ovanie - roztried’ovanie na základe určitého kritéria).

- Využívanie asociácií (prvotné predstavy spojené s istým pojmom, javom).

- Identifikácia a vymedzenie základných pojmov a vzt’ahov učitel’om, tvorba poznámok.

- Vedenie žiakov k tvorbe originálnych myšlienok, riešení a produktov. F3 - Stratégie argumentácie. Faktorová analýza zahrnula do faktoru 6 položiek s nasledujúcimi stratégiami:

- Využitie protirečení a rozporov, vedenie k argumentácii.

- Vedenie žiakov k identifikácii rozdielov medzi faktom a názorom.

- Vedenie žiakov k grafickému znázorňovaniu učiva (pojmové mapy, handout, tabul'kové, grafické znázornenia).

- Vedenie žiakov $\mathrm{k}$ hodnoteniu dôveryhodnosti zdroja, vedenie $\mathrm{k}$ argumentácii.

- Vedenie $\mathrm{k}$ aplikácii učiva $\mathrm{v}$ neobvyklých situáciách a úlohách.

- Využívanie metódy hranie rolí.

F4 -Stratégie pre vyvodzovanie záverov a riešenie problémov. Faktorová analýza zahrnula do faktoru 8 položiek s nasledujúcimi stratégiami:

- Využívanie rôznych zdrojov (okrem učebnice).

- Vedenie žiakov $\mathrm{k}$ vyvodzovaniu záverov a k zovšeobecňovaniu.

- Rešpektovanie medzipredmetových vzt’ahov.

- Využívanie debaty vo vyučovaní (vedenie k tvorbe analýz a argumentov).

- Vedenie $\mathrm{k}$ formulovaniu otázok podporujúcich myslenie (otázky typu: Čo je podstatou toho? Čo to znamená? Prečo sa to deje? Čo keby? a pod. ).

- Vytváranie priestoru pre prezentovanie žiakových myšlienok, ich konfrontáciu a zdokonal'ovanie.

- Vedenie žiakov k identifikácii, pomenovaniu problémov.

- Riešenie problému a navrhovanie záverov.

F5 -Stratégie na rozvoj hodnotenia. Faktorová analýza zahrnula do faktoru 4 položky s nasledujúcimi stratégiami:

- Vedenie žiakov $\mathrm{k}$ identifikácii kl’účových a relevantných faktov a myšlienok $v$ učive.

- Vedenie žiakov k identifikácii príčiny a následku.

- Kladenie otázok zameraných na opakovanie zapamätaného učiva.

- Štruktúrovanie učiva na základe vymedzených ciel'ov podla konkrétnych taxonómií (Bloom, Simpson, Harrow, Krathwohl, Tollinger....).

F6 - Stratégie na rozvoj čitatel'ských zručností. Faktorová analýza zahrnula do faktoru 4položieky s nasledujúcimi stratégiami:

- Využívanie digitálnych učebných materiálov, programov a aplikácií.

- Využívanie grafických znázornení pri prezentácií učiva (pojmové mapy, handout, tabul'kové, grafické znázornenia). 
- Vedenie $\mathrm{k}$ práci s textom a $\mathrm{k}$ tvorbe vlastných poznámok.

- Vytváranie prezentácií a podporných učebných materiálov pre žiakov.

Zaradenie položiek $6,7,8,9,14,15,16,18,21,26,31,32,36,40$ je zároveň problematické, nakol'ko položky významne sýtia viac než jeden faktor. Konkrétne položka Využivanie projektového vyučovania sýti okrem faktora F1 - Stratégie na rozvoj sebaregulácie aj faktor F3 - Stratégie argumentácie. Položka Vytváranie priestoru pre sebaprezentáciu, prezentáciu vlastných riešeni žiakov sýti okrem F1 aj faktor F2 - Stratégie na rozvoj systematických a interpretatívnych zručností. Položka Vytváranie priestoru pre prezentovanie rôznych názorov, postojov a kultúrnych odlišností medzi žiakmi sýti okrem F1 zároveň faktor F2 - Stratégie na rozvoj systematických a interpretatívnych zručností; Podobne položka Preferencia úloh s väčším počtom správnych riešení sýti okrem F1 aj faktor F3 - Stratégie argumentácie.

Štyri položky faktora F2 vykazujú hodnoty koeficientov nasýtenia nad 0,300 aj v niektorom z d'alších faktorov. Konkrétne položka Preferencia kognitívne náročnejšich úloh (úlohy na analýzu, hodnotenie, tvorivost') s jedným správnym riešením, sýti aj faktor F3 Stratégie argumentácie; Položka Vedenie žiakov k tvorbe originálnych myšlienok, riešení a produktov sýti zároveň faktor F1 - Stratégie na rozvoj sebaregulácie, rovnako ako položka Využivanie kategorizácií. Položka Využitie postupov na zapamätávanie sýti zároveň faktor F5 - Stratégie na rozvoj hodnotenia. Z položiek faktora F3 Stratégie argumentácie môžeme ako problematickú hodnotit’ jednu položku, konkrétne položku Vedenie k aplikácii učiva v neobvyklých situáciách a úlohách, ktorá zároveň dosahuje vysoké hodnoty koeficientu nasýtenia aj vo faktore F1 a F2. Položka Vedenie žiakov k identifikácii rozdielov medzi faktom a názorom sýti zároveň aj faktor F5 - Stratégie na rozvoj hodnotenia.

Faktor 4 Stratégie pre vyvodzovanie záverov a riešenie problémov vykazuje dve problematické položky. Položka Vedenie kformulovaniu otázok podporujúcich myslenie (otázky typu: Čo je podstatou toho? Čo to znamená? Prečo sa to deje? Čo keby? a pod.) sýti tiež faktor F2 - Stratégie na rozvoj systematických a interpretatívnych zručností a položka Vedenie žiakov $k$ vyvodzovaniu záverov a k zovšeobecňovaniu sýti tiež faktor F5 - Stratégie na rozvoj hodnotenia.

Faktor 5 Stratégie na rozvoj hodnotenia má jednu problematickú položku Vedenie $k$ práci $s$ textom a k tvorbe vlastných poznámok, ktorá zároveň sýti faktor F6 - Stratégie na rozvoj čitatel'ských zručností. Podobné sýtenie faktorov F5 a F6 sme zaznamenali aj v položke Využivanie grafických znázorneni pri prezentácii učiva (pojmové mapy, handout, tabulkové, grafické znázornenia).

Problematickost' zaradenia jednotlivých položiek je daná pravdepodobne samotnou podstatou myslenia. Ako konštatoval Van Galder (2005) myslenie je viac ako súhrn jeho častí a rovnako ako kritické myslenie, ani stratégie na jeho rozvíjanie nie je možné vystavat' na presnom popise stratégií rozvíjajúcich izolovane vymedzené zručnosti, či myšlienkové operácie. I k predmetnej faktorovej analýze nepristupujeme s takouto snahou, ale s ambíciou pomôct' odborovým didaktikom, cvičným učitel'om a učitel'om jednotlivých predmetov uchopit' stratégie rozvíjajúce kritické myslenie 
a pripravit ich transfer do kurikula príslušných prírodovedných, spoločenskovedných, jazykových, umelecko-výchovných i výchovných predmetov, ktorý bude založený na interdisciplinárnych väzbách a povedie k spoločnému ciel'u: výchove kriticky mysliaceho človeka s otvorenou mysl'ou, prirodzene zvedavého, flexibilného, chápajúceho rozmanité hl'adiská, pátrajúceho po nových informáciách, zvažujúceho rôzne argumenty a rôzne riešenia, hl'adajúceho d'alšie perspektívy a argumenty pre formuláciu konečných rozhodnutí. Tento ciel' je však dosiahnutel'ný len tak, že učitel' bude schopný zvolit' také vyučovacie postupy, ktoré priamo stimulujú rozvoj sebaregulácie, rozvoj systematických a interpretatívnych zručností, argumentácie, vedú $k$ vyvodzovaniu záverov a riešeniu problémov, $k$ hodnoteniu a v neposlednom rade $k$ rozvoju čitatel'ských zručností.

\section{ZÁVER}

Faktorová analýza položiek dotazníka Stratégie kritického a tvorivého myslenia vo vyučovaní (Duchovicova a kol., 2017) umožnila autorom vymedzit' šest' faktorov - kl'účových strategických postupov vo vyučovaní pre rozvoj kritického a tvorivého myslenia. Uvedené faktory umožnia výskumníkom vyhodnotit' preferencie konkrétnych stratégií rozvíjania kritického myslenia učitel'mi v konkrétnych vyučovacích predmetoch, identifikáciu stratégií uplatňovaných cvičnými učitel'mi v rámci pedagogických praxí študentov učitel'ských programov v závislosti od vyučovaných predmetov (prírodovedné, jazykové, spoločenskovedné, výchovné), type školy (SOŠ, gymnázium, II. stupeň ZŠ) a stupňa vzdelávania (nižšie a vyššie sekundárne vzdelávanie). Očakávame, že jednotlivé zistenie povedú k zásadným zmenám metodík konkrétnych predmetov v jednotlivých odborových didaktikách so zahrnutím stratégie na rozvoj sebaregulácie; stratégie na rozvoj systematických a interpretatívnych zručností, stratégie argumentácie, stratégie pre vyvodzovanie záverov a riešenie problémov, stratégií na rozvoj hodnotenia a stratégií na rozvoj čitatel'ských zručností.

Táto práca bola podporovaná Agentúrou na podporu výskumu a vývoja na základe Zmluvy č. APVV-15-0368.

\section{Bibliographic references}

ABRAMI, P. C. - BERNARD, R. M. - BOROKHOVSKI, E. - WADE, A. SURKES, M. A. - TAMIM, R. - ZHANG, D. 2008. Instructional interventions affecting critical thinking skills and dispositions: A stage 1 meta-analysis. Review of Educational Research, vol. 78, n. 4, 1102-1134.

ANDERSON, L.W. - KRATHWOHL, P. 2001. A Taxonomy for Learning, Teaching a Assesing of Educational Objectives. New York: Longman,

ARANGIE, P.A.R. 1997. Critical thinking: the path to the future. Tennessee Nurse, vol. 60, n. 3, pp.15-16.

BAILIN, S. 2002. Critical thinking and science education. Science \& Education, vol. 1, n. 4, pp. 361-375.

BAILIN, S. - CASE, R. - COOMBS, J. R. - DANIELS, L. B. 1999. Conceptualizing critical thinking. Journal of Curriculum Studies, vol. 31, n. 3, pp. 285-302. 
BELL, E.A. 1991. Debate: a strategy for teaching critical thinking. Nurse Educator, vol. 16, n. 2, pp. 6-7.

BONK, C. J. - SMITH, G. S. 1998. Alternative instructional strategies for creative and critical thinking in the accounting curriculum. Journal of Accounting Education, vol. 16, n. 2, pp. 261-293.

CASE, B. 1994. Walking around the elephant: a critical thinking strategy for decision making. The Journal of Continuing Education. Nursing, vol.25, n. 3, pp.101-109.

CASE, R. 2005. Moving critical thinking to the main stage. Education Canada, vol. 45, n.2, pp. 45-49.

CAPEK, R. 2015. Moderni didaktika. Praha_: Grada.

DUCHOVICOVA, J. A KOL. 2017. Strategie kritickeho a tvoriveho myslenia vo vyucovani. Dotaznik pre studentov. (doteraz nepublikovane)

DUCHOVICOVA, J. - SKODA, J. a kol. 2013. Psychodidakticke pojeti kurikularniho a mediacniho kontextu edukace. Usti nad Labem: PF UJEP, 290 s.,

ENNIS, R. H. 1985. A logical basis for measuring critical thinking skills. Educational Leadership, vol. 43, n.2, pp. 44-48.

ERDURAN, S. - JIMENEZ, M. P. A. 2008. Argumentation in science education: Perspectives from classroom based research. Dordrecht: Springer.

FACIONE, P. A. 1990. Critical thinking: A statement of expert consensus for purposes of educational assessment and instruction. Reserch Findings and. Recommendations. Newark: APA

FACIONE, N.C. - FACIONE, P.A. - BLOHM, S.W. - HOWARD, K. GIANCARLO. C.A. 1998. The California Critical Thinking Skills Test ( CCTST): forms A and B and test manual (revised ed). Millbrae CA: California Academic Press.

FISHER, R. 2004. Učíme deti myslet a učit se. Praha_: Portál.

HALPERN, D. F. 2014. Trought and Knowledge. An Introduction to Critical Thinking. (5 ed.) New York, London: Taylor \& Francis,

HATTIE, J. A. C. 2003. Teachers Make a Difference: What is the Research

Evidence?[online]. Australian Council for Educational Research [cit. 21. 12.

2014].

Available online:

https://cdn.auckland.ac.nz/assets/education/hattie/docs/teachers-makeadifference-ACER-\%282003\%29.pdf

HEYMAN, G. D. 2008. Children's critical thinking when learning from others. Current Directions in Psychological Science, vol.17, n. 5, pp.344347.

KENNEDY, M. - FISHER, M. B. - ENNIS, R. H. 1991. Critical thinking: Literature review and needed research. In L. Idol \& B.F. Jones (Eds.), Educational values and cognitive instruction: Implications for reform. Hillsdale, New Jersey: Lawrence Erlbaum \& Associates. (pp. 11-40)

KING, A. 1995. Designing the instructional process to enhance critical thinking across the curriculum. Teaching of Psychology, vol. 22, n. 1, pp.13-17. 
KNEEDLER, P. 1985. California Assessing Critical thinking. In A. Costa (Ed.), Developing Minds: A Resource Book for Teaching Thinking. Alexandria VA: Association for Supervision and Curriculum Development.

KOSTURKOVA, M. 2012. Možnosti využitia stratégie E-U-R v edukácii. Pedagogické rozhl'ady, vol. 21., n. 1-2, p. 1- 5.

KOSTURKOVA, M. 2011.Rozvoj kritického myslenia u študentov vysokých škôl. Zborník prác z vedeckej konferencie MVEK, Prešov : FHPV PU, s.526 LAI, E. R. 2011. Critical thinking: A Literature Review. [cit. 20.12.2015] Available

online: http://images.pearsonassessments.com/images/tmrs/CriticalThinkingReviewF INAL.pdf

LIPMAN, M. 1988. Critical thinking-What can it be? Educational Leadership, vol.46, n.1, pp. 38-43.

NELSON, C. E. 1994. Critical thinking and collaborative learning. New Directions for Teaching and Learning, 59, 45-58.

OBRANCOVA, E. a kol. 2004. Štúdia PIRLS. Bratislava: ŠPU

OECD TALIS, 2008. Prax ucitelov slovenskzch skol na nizsom sekundarnom stupni z pohladu medzinarodneho vyskumu. Narodna sprava. Bratislava : NÚCEM, 2010.

PAUL, R. 1993. Critical thinking . Santa Rosa, California: The Foundation for Critical Thinking

PAUL, R. W. 1992. Critical thinking: What, why, and how? New Directions for Community Colleges, 77, p. 3-24.

PAUL, R. W. - ELDER, L. 2006. Critical thinking: The nature of critical and creative thought. Journal of Developmental Education, vol. 30, n. 2, pp. 3435.

PASCARELLA, E. - TERENZINI, P. 2005. How college affects students. San Francisco: Jossey Bass

Preparing Teachers around the World 2003 [online] Educational Testing Service. [cit. 20.11.2014] Available online: http://www.ets.org/Media/Education_Topics/pdf/prepteach.pdf

SIMPSON, E. - COURTNEY, M. 2007. The development of a critical thinking conceptual model to enhance critical thinking skills in middle-eastern nurses: a middle-eastern experience. Australian journal of advanced nursing, vol. 25, n. 1, pp. $56-63$.

SKALKOVA, J. 2004. Pedagogika a vyzvy novej doby. Brno: Paido, $154 \mathrm{s.}$ SPILKOVA, V. - TOMKOVA, A. a kol. 2010. Kvalita ucitele a profesni standard. Praha : Univerzita Karlova Pedagogicka fakulta,

Standards of Effective Practice for Teachers 2009. [online] The Office of the Revisor of Statutes. Minnesota Administrative Rules [cit. 1. 10. 2014]. Available online: https://www.revisor.mn.gov/rules/?id=8710.2000

Standards of Practice. 2013. [online] Ontario College of Teachers [cit. 1. 10. 2014]. Available online: http://www.oct.ca/public/professionalstandards/standars-ofpractice

STERNBERG, R. J. 1986. Critical thinking: Its nature, measurement, and improvement National Institute of Education. Available online: http://eric.ed.gov/PDFS/ED272882.pdf 
TALIS RESULTS 2013 [online] OECD. [cit. 1. 10. 2014]. Available online: http://www.keepeek.com/Digital-Asset-Management/oecd/education/talis2013-results_9789264196261-en\#page3

THAYER BACON, B. J. 2000. Transforming critical thinking: Thinking constructively. New York: Teachers College Press.

TINDAL, G. - NOLET, V. 1995. Curriculum-based measurement in middle and high schools: Critical thinking skills in content areas. Focus on Exceptional Children, vol. 27, n. 7, pp. 1-22.

VAN GELDER, T. 2005. Teaching critical thinking: Some lessons from cognitive science. College Teaching, vol. 53, n. 1, pp. 41-48.

WALSH, K. 1997. Teaching tools: What if? What else? What then? A critical thinking game. Nurse Educator, vol. 22, n. 5, pp. 9-12.

WILLINGHAM, D. T. 2007. Critical thinking: Why is it so hard to teach? American Educator, 31, 8-19. [cit. 20.07.2017] Available online: http://www.aft.org/sites/default/files/periodicals/Crit_Thinking.pdf

ZULJAN VALENCIC, M. - VOGRINC, J. (ed.) 2011. European Dimensions of Teacher Education - Similarities and Differences. Ljubjana: Faculty of Education, University of Ljubljana, 2011.

doc. PaedDr. Jana Duchovičová, PhD.

Univerzita Konštantína Filozofa v Nitre

Pedagogická fakulta, Katedra pedagogiky

Dražovská cesta 4, 94974 Nitra

Slovakia

jduchovicova@ukf.sk

PaedDr. Robert Tomšik

Univerzita Konštantína Filozofa v Nitre

Pedagogická fakulta, Katedra pedagogiky

Dražovská cesta 4, 94974 Nitra

Slovakia

robert.tomsik@ukf.sk 